\title{
The Types of Communication Strategies Used by The English Teacher of SLB Negeri 1 Gianyar in Teaching Deaf or Hard of Hearing Students
}

\section{Dewi, N.K.M ${ }^{1}$}

${ }^{1}$ Universitas Pendidikan Ganesha, Singaraja, Indonesia

ARTICLE IN F O

Article history:

Available online on

February, $20^{\text {th }} 2018$

Keywords:

Communication strategies,

CM for D/HH students,

Deaf or hard of hearing

students

\begin{abstract}
A B S T R A C T
This present study aimed at finding out the types of communication strategies used by the English teacher to communicate with $\mathrm{D} / \mathrm{HH}$ students during teaching and learning process in the classroom, the teacher's reason used those communication strategies and whether the teacher communicate with each student the same ways or not. This present study was a case study with qualitative approach. The subject of this study was an English teacher of Senior High School who teach D/HH students in SLB Negeri 1 Gianyar. The data was collected by using observation sheet, interview guide, and audio-video recorded. Then, the data was analyzed descriptively by using three steps, namely data reduction, data display, and conclusion drawing or verification. The results of the study show that there are 7 types of communication strategies used by the English teacher to communicate with D/HH students, namely: lips or speech reading, sign language, cued speech, total communication, conceptual language, visual media, and literal translation. The main reason why the English teacher used those communication strategies was in order to ease him to communicate with $\mathrm{D} / \mathrm{HH}$ students and help him in explaining the material toward D/HH students. Then, it was found that the English teacher used different communication strategies to communicate with each student. Based on the finding above, the teacher used all types of communication strategies in every class and supported by logical reasons.
\end{abstract}




\section{Introduction}

In teaching and learning context, communication is very important for both teacher and students. In this case, the students communicate with their teacher and friends in order to get new knowledge. Through communication the student can share their knowledge and the students also will be able to share information with the teacher or their friends about what they know or do not know. This process will enrich students' knowledge. Furthermore, through communication the teacher also can recognize the problem face by the students. By knowing the problems faced by the students in learning, the teacher can use appropriate strategy that are suitable for the student, so it can solve the problem that faced by the students. Based on those explanations, we need to consider about the strategies that will be used to communicate with the students. According to Maleki (2010) he mentions that using communication strategies is pedagogically effective in language teaching. The use of communication strategies is recommended strategies for teaching to cope the communication problem that maybe appear when teaching English.

Learning foreign language is already hard for normal hearing student, and then it must be more difficult for special needs students especially deaf or hard of hearing $(\mathrm{D} / \mathrm{HH})$ students because of their limit and less media to help them in learning. In line with that statement, Senko (2010) states that the accommodations that offered for D/HH students for their specific needs are less and inappropriate. The teacher also maybe sometimes struggle to find an appropriate grammatical construction or expression when trying to communicate or convey their meaning. That is why the teacher needs to think and consider about the appropriate communication strategies for teaching D/HH students in order to make effective communication with the students so they will be able to understand the learning material well.

Furthermore, teacher needs to use many communication strategies to handle possible communication problem when explaining the material. Communication strategies can be seen as strategy for solving someone's problem in reaching their communication goal. In line with this statement Faerch and Kasper (1983), state that communication strategies are "potentially conscious plans for solving what an individual presents itself as a problem in reaching a particular communicative goal". Communication strategies will help the teacher to reduce their difficulties while transferring their thoughts and ideas to D/HH students.

D/HH students have a problem in communication, this problem occurs because of the students experience hearing loss or hard of hearing. The hearing loss, make the students lack in communication skill. Those situations make the students obstacles in receiving, processing, and storing the information during teaching and learning process. In line with those statements Howard (2007) states that D/HH students usually have more troubles in gathering information. For children with hearing impairment, their inability to hear and receive audio information makes them faced difficulties in communicating. The teachers in special education have a crucial role. If the teachers are able to use appropriate communication strategies, there will be higher possibility that the process in transferring the learning materials or information will run effectively and the students can understands the learning materials and get the meaning or the messages that the teacher want to share.

Moreover, the teacher needs to pay more attention with the communication strategies they used during teaching foreign language such as English. Learning English already hard for normal hearing students, it must be more difficult for $\mathrm{D} / \mathrm{HH}$ students. The limitless in hearing will make the students face obstacle during teaching and learning process. Then, with the hearing barriers experience by $\mathrm{D} / \mathrm{HH}$ students then various communication strategies need to be used by the teacher during teaching and learning process to cope the communication problems that maybe appear. Faerch and Kasper (1983) state, communication strategies usually refers to the devices used by foreign language learners to cope with their oral communication problems in order to achieve their communicative goals. In the previous study also found that the used of communication strategies help D/HH students and the teacher in communicate. Huti (2016), she found that the English teacher used communication strategies are helping them to communicate with the D/HH students and also to help D/HH to communicate with each other.

By regarding the important of communication strategy for both teachers and students in special school especially in $\mathrm{D} / \mathrm{HH}$ classes, therefore, this study purposed at investigating the types of communication strategies used by the English teacher to communicate with D/HH students during teaching and learning process in the classroom, the teacher reason used those communication strategies, and whether the teacher used different communication strategies to communicate with each student. Furthermore, this study was conducted at SLB Negeri 1 Gianyar. 


\section{Methods}

The approach of this research was qualitative approach, in which the method of data collection and data analysis was done qualitatively. The qualitative approach was used to gather information focuses on describing a phenomenon in a deep comprehensive manner. Furthermore, this research was a case study. According to Fraenkel, Wallen, and Hyun (2012) a case study is a detailed study of one or (at most) a few individuals or other social units, such as a classroom, a school, or a neighborhood. It can also be a study of an event, an activity, or an ongoing process.

\subsection{Subject and Object of the Study}

The subject of this study was an English teacher of Senior High School who teach D/HH students in SLB Negeri 1 Gianyar. Then, the object of the study was the communication strategies used by the English teacher of Senior High School during teaching and learning process in the classroom.

\subsection{Methods of Data Collection}

The data was collected by using observation sheet, interview guide, and audio-video recorded. The observation sheet was used to observe the types of communication strategies used by the English teacher to teach $\mathrm{D} / \mathrm{HH}$ students in English lesson. Then, the interview guide was a list of question that the researcher was used to ask information to the teacher about the reasons why the teacher used certain communications strategies and the ways the teacher communicate with each student in the classroom. Video recorder was used to record teaching and learning process to know types of communication strategies that used by the English teacher to communicate with D/HH students in the classroom during English lesson. Furthermore, Audio recorder was used to record the conversation when the researcher interviews the teacher to find out the teachers' reasons in using certain types of communication strategies to communicate with $\mathrm{D} / \mathrm{HH}$ students and whether the teacher communicate with each students in the same ways or not.

\subsection{Triangulation Data}

In collecting the data, the researcher should examine the accuracy or credibility of the data in order to avoid bias in the result of the study. According to Creswell (2012) triangulation or member checking strategies can used to verify the data to determine the accuracy or credibility of the findings. In this research, the researcher used triangulation to determine the credibility of the data.

\subsection{Data Analysis}

Based on Miles and Huberman (1994), there are three steps that the researcher should do in order to analyze the data, namely data reduction, data display, and conclusion drawing or verification. The activity in analyzing the data should be done interactively and ongoing process until there is no recent data.

\section{Findings and Discussion}

\subsection{Types of Communication Strategies Used by the English Teacher during Teaching and Learning Process}

After conducting the research, there were 7 communication strategies used by the English teacher to communicate with $\mathrm{D} / \mathrm{HH}$ students during teaching and learning process in the classroom. Those are lips or speech reading, sign language, cued speech, total communication, conceptual language, visual media, and literal translation.

The English teacher used lips reading strategy to communicate with D/HH students during teaching and learning process in the classroom. In this strategy, the English teacher would make a lips movement and say or pronounce the words, and then D/HH students could read his lips movement. This strategy help the students how to pronounce the words. This communication strategy that used by the English teacher in SLB Negeri 1 Gianyar is in accordance with what is stated by Doyle and Dye (2002) about lips or speech reading. They state that children who are with moderate hearing loss, severe hearing loss, and also 
profound hearing loss need to give lips reading or speech reading exercise. This exercise will help them to know what is said by the teacher because they only rely on their vision and they also difficult to hear loud sound or voice even in a close distance. In addition, Wulansari (2012) also states that, speech reading is one of the strategies that use by D/HH people to communicate.

The English teacher also used sign language from the beginning of the lesson until the end of the lesson to communicate with D/HH students. The used of sign language in D/HH classes is a must because the main strategy that used by the $\mathrm{D} / \mathrm{HH}$ students to communicate with each other in their daily life is sign language. Sign language is very important for D/HH people because they are difficult or unable to hear voice or sound. In line with those statements, according to Somantri (as cited in Wulansari, 2012), one of the strategies that used by D/HH people to communicate is sign language. In addition, according to Khoir (2014) Deaf people used sign language as their primary communication tool.

Furthermore, the researcher found that the English teacher used cued speech to communicate with $\mathrm{D} / \mathrm{HH}$ students during teaching and learning process in the classroom. When the teacher used cued speech strategy, the teacher combined some strategy. In this case, the teacher used lips reading while producing sound and used sign language strategy at the same time. According to Doyle and Dye (2002), cued speech helps the listener visually distinguish between similar looking sounds on the speaker lips movement. It is because when the speaker used cued speech strategy, the speaker used some strategies at the same time such lips reading while speaking and simultaneously use hand gesture. In addition, according to Khoir (2014), children who are experience mild hearing loss are able hear speech at very close distance.

The researcher also found that the English teacher used total communication to communicate with $\mathrm{D} / \mathrm{HH}$ students during teaching and learning process in the classroom. Total communication is a combination of lips reading/speech reading, sign language, writing the word and cued speech. During the observation the researcher found that the teacher combined some strategies to communicate with $\mathrm{D} / \mathrm{HH}$ students. In the process of teaching and learning process in the classroom, it was found that the teacher used more than one strategy at the same time. Those combinations of communication strategies can ease the teacher when explaining the material to D/HH students. According to Doyle and Dye (2002), they states that total communication is "a philosophy of communication that employs a combination of components of oral and manual teaching modes using sign, lips reading, finger spelling, use of residual hearing, speech, and sometimes Cued Speech". Besides that, Hanum and Hermawati (2014), also said that the aims of total communication is to achieve effective communication between fellow def or deaf people with normal people by using media to speak, lips reading, auditory training, sign language (gesture and finger spelling) in an integrated manner.

Conceptual language is one of the communication strategies that can be used to communicate with D/HH students. Based on the interview that conducted by the researcher, the teacher said that the sign or gesture is created by the students and the teacher used it in order to make them easier to understand. According to Wicaksono (2012), conceptual language (natural or pure sign language) is a manual sign which is agreed or approved between the users. Those sign is unofficial sign which is only used by a group of people in a certain area and it does not exist in SIBI (Sistem Isyarat Bahasa Indonesia).

Then, the teacher also used visual media to communicate with D/HH students. Visual media used by the teacher as a tool to communicate with the students. in line with those statements, Kustandi and Sutjipto (as cited in Zakiai, Sunardi, and Yamtinah, 2017) they state that "media as a learning tool can help the process of teaching and learning and to clarify the meaning of the message, so that it can contribute to achieve the goal of learning". So the use of these learning media will greatly assist in teaching D/HH students. In addition, Sartika (as cited in Zakiai, Sunardi, and Yamtinah, 2017) suggested the suitable learning media for deaf children with disabilities in speaking and hearing, she suggests to use visual media in teaching. Doyle and Dye (2002) also states that, visual method (media) is needed by profound hearing loss as acquire language and communicate. Visual media can help the teacher to communicate with $\mathrm{D} / \mathrm{HH}$ students during teaching and learning process in the classroom.

Besides that, it was found that the teacher used communication strategies that used by normal hearing people to communicate with $\mathrm{D} / \mathrm{HH}$ students, namely literal translation. Literal translation is one of the classifications of communication strategies that can be used by normal hearing people that proposed by Tarone (1980) and Dornyei (1995) in their study. According to Tarone (1980), literal translation is the speaker translates the word for word from the native language. Based on the observation that has been done by the researcher, it showed that the students have limited English vocabulary. During teaching and learning process the teacher need to translate each word from Indonesian language to English and write it in the whiteboard, so the students could take a note. This strategy helps the teacher to make the students to know the language and communicate with the students. Furthermore, based on the interviewed the teacher said that, this strategy help the teacher introducing 
the new vocabulary to the students. He adds that sometimes the students know the sign of the words but does not know how to write it. Based on that observation and interview, it showed that this strategy is helpful and useful for the teacher during teaching and learning to transfer the material or to communicate with $\mathrm{D} / \mathrm{HH}$ students.

The result of this study was also supported by the empirical studies that were mentioned in Chapter II and the finding in previous studies with the same topics. There are some similarities that found by the researcher. In 2010, Wisadirana, Safitri, and Swastikawara conducted a study entitle "Strategi Komunikasi Guru dalam Mengasah Kemampuan Komunikasi Pada Murid Tunarung (Studi Kasus pada SDLB-B YPTB Malang ". They found that D/HH students used sign language and total communication strategies to communicate with others. Then, in 2014, Khoir conducted a study entitled "Pola Komunikasi Guru dan Murid di Sekolah Luar Biasa B (SLB-B) Frobel Montessori Jakarta Timur". This study investigated the implementation of communication strategy that used by the teacher in teaching at SDLB B Frobel Montessori. He found that the communication strategies that used by the teacher in teaching students who are deaf or hard of hearing are lips reading and sign language.

Besides those two studies, another studies by Cicilia (2015) and Huti (2016) also found similar communication strategies that could be used to communicate with D/HH students. According to Cicilia (2015), she conducted a study entitled "Komunikasi Instruksional Guru pada Proses Pembelajaran Siswa Tunarungu Jenjang Sekolah Menengah Atas (SMA) Di Sekolah Luar Biasa (SLB) Sri Mujinab Pekanbaru". She found that the teacher used sign language (hand movement, body language and face expression), oral method (mouth action and face expression), total communication (combination between sign language and oral method), audiovisual (video) and visual media (Figure, the original object, artificial object). Moreover, according to Huti (2016), she conducted a study entitled "The Type of Communication Strategies used by the Teacher to Deaf or Hard of Hearing Students during Teaching and Learning Process in SLBN B Singaraja". In her study, it was found that the English teachers used six types of communication strategy to communicate with the D/HH students, namely lips or speech reading, sign language, cued speech, total communication, visual media, and also conceptual language strategies.

\subsection{The Reasons of the English Teacher Used those Communication Strategies}

Based on the result of observation and interview, the researcher found that the teacher's reason used lips or speech reading, sign language, cued speech, total communication, conceptual language, visual media, and literal translation in communicating with $\mathrm{D} / \mathrm{HH}$ students during teaching and learning process in the classroom. The use of communication strategies in $\mathrm{D} / \mathrm{HH}$ classes is very important for the teacher and students. In selecting the communication strategies the teacher considers about the students' ability. The English teacher said that, he used some of the strategies such as lips or speech reading, and cued speech in order to maximize the students' ability in hearing and speaking. The teacher wants to train the students how to pronounce the words.

\subsection{The Communication Strategies Used by the English Teacher to Communicate with Each Student}

Based on the result of observation and interview, it can be assumed that during teaching and learning process when the teacher communicated with the students individually, it showed that the teacher used different communication strategies. During the observation the researcher found that the teacher used different communication strategies to communicate with each student. Furthermore, based on the interview, the teacher reveals that the students in D/HH classes experience different hearing loss. He also stated that, he used different communication strategies to communicate with D/HH students. Then, in using the communication strategies to communicate with D/HH students, the teacher considered with the students' hearing condition and students' ability.

Moreover, he said that, he using different strategies in order to provide an explanation in accordance with the ability of the students. He used communication strategy that mastered by student so that student can more quickly understand. He adds that, his mains goal in using different communication strategies to communicate with each student is to improve and optimize students' abilities. The used of different communication strategies by the teacher when communicate with each students will give a good effect toward the students. By considering the students hearing condition and the communication strategies that mastered by the students will make the students easier to understand what it means by the teacher, because the teacher used communication strategies that the students mastered and the strategies that can maximize the students' ability.

Furthermore, by using different communication strategies to communicate with each students during teaching and learning process in English lesson can cope the communication problem that appear 
during teaching and learning process between the teacher and D/HH students. In line with that statement, Faerch and Kasper (1983) state, communication strategies usually refers to the devices used by foreign language learners to cope with their oral communication problems in order to achieve their communicative goals.

\section{Conclusion}

Based on the result of data analysis in previous chapter, some conclusions could be described as follows:

1. It was found 7 types of communication strategies that used by the English teacher to communicate with $\mathrm{D} / \mathrm{HH}$ students during teaching and learning process in the classroom. There were (a) Lips or Speech Reading, (b) Sign Language, (c) Cued Speech, (d) Total Communication, (e) Conceptual Language, (f) Visual Media, and (g) Literal Translation.

2. The reasons of the teacher used those communication strategies are to maximize D/HH students' ability in hearing and speaking. Then, the English teacher also wanted to train the students to speak. Furthermore, the English teacher used those strategies in order to facilitate him to communicate and explain the material toward D/HH students. In addition, the English teacher choosing the communication strategies that usually used by $\mathrm{D} / \mathrm{HH}$ students to communicate in their daily life.

3. The English teacher used different communication strategies to communicate with each student. The English teacher used different communication strategies by considering the students' hearing condition and students' ability.

\section{References}

Creswell, J. W. (2005). Educational research: Planning, conducting, and evaluating quantitative and qualitative research. Upper Saddle River, N.J: Merrill.

Cicilia, P. (2015). Komunikasi instruksional guru pada proses pembelajaran siswa tunarungu jenjang sekolah menengah atas (sma) di sekolah luar biasa (slb) sri mujinab pekanbaru. Jom FISIP, 2(1), $1-16$.

Dornyei, Z. (1995). On the teachability of communication strategies. TESOL Quartely, 29(1), 55-85.

Doyle, M \& Dye, L. (2002). Mainstreaming the students who is deaf or hard of hearing. San Diego: N.p., Print

Faerch, C., \& Kasper, G. (1983). Plans and strategies in foreign language communication strategies of thai university students. Journal of Humanities, 17, 20-60.

Fraenkel, J. R., Wallen, N. E., \& Hyun, H. H. (2012). How to Design and Evaluate Research education. New York: McGraw-Hill.

Hanum, A. N. \& Hermawati, E. (2014). Strategi komunikasi total dan interaksi simbolik dengan anak tunarungu di sekolah luar biasa (slb) dharma asih pontianak. Prosiding SNaPP2014 Sosial, Ekonomi, dan Humaniora, 4(1), 281-287.

Howard, W. (2007). Teaching strategies for the deaf and hearing impared. (2nd ed).

Huti, N. K. G. D. (2016). The Types of Communication Strategies used by the Teacher to the Deaf or Hard of Hearing Students during the Teaching and Learning Process in SLBN-B Singaraja. Unpublished thesis of Undiksha Singaraja.

Khoir, M. S. (2014). Pola komunikasi guru dan murid di sekolah luar biasa b (slb-b) frobel montessori Jakarta timur. Universitas Islam Negeri Syarif Hidayatullah.

Maleki, A. (2010). Techniques to teach communication strategies. Journal of labguage teaching research, 1(5), 640-646.

Miles, M.B., \& Huberman, A.M., (1994). An expanded sourcebook: Qualitative data analysis. London : Sage Publications.

Senko, L. (2010). Addressing the unique needs of hard of hearing students in diverse school setting. TCNJ Journal of student scholarship, 12, 1-10. 
Tarone, E. (1980). Some thoughts on the notion of communication strategy. TESOL Quarterly, 15(3), 285295.

Wicaksono, G. (2012). Hubungan penguasaan bahasa (oral dan bahasa isyarat) terhadap kemampuan membaca permulaan siswa kelas 1 sekolah dasae sln n kota magelang tahun ajaran 2011/2012. Universitas Sebelas Maret Surakarta.

Wulansari. W. (2012). Teknik komunikasi non-verbal guru pada penyandang tunarungu. Universitas Sultan Ageng Tirtayasa.

Wisadirana, D., Safitri, R., \& Swastikawara, S. (2010). Strategi komunikasi guru dalam mengasah kemampuan komunikasi pada murid tunarungu (studi kasus pada SDLB-B YPTB malang). Jurnal Interaktif, 1(2), 168-181.

Zakiai, D. L., Sunardi, \& Yamtinah, S. (2017). The study of visual media use on deaf children in science learning. European Journal of Special Education Research, 2(1), 105-115. 